\title{
Prevalence of Extraglandular Manifestations in Patients With Primary Sjögren's Syndrome in Southern Norway: A Comparison to the Literature
}

\author{
Lars JORKJEND, ${ }^{1}$ Anders JOHANSSON, ${ }^{2}$ Ann Katrin JOHANSSON ${ }^{3}$ \\ ${ }^{1}$ University of Oslo, Section of Dental Pharmacology and Pharmacotherapy, Oslo, Norway \\ ${ }^{2}$ Department of Clinical Dentistry-Prosthodontics, University of Bergen, Faculty of Medicine and Dentistry, Bergen, Norway \\ ${ }^{3}$ Department of Clinical Dentistry-Cariology, University of Bergen, Faculty of Medicine and Dentistry, Bergen, Norway
}

\begin{abstract}
Objectives: This study aims to investigate the prevalence of extraglandular manifestations (EGM) in a group of Norwegian patients suffering from primary Sjögren's syndrome (pSS) and compare these findings with the literature.

Material and methods: Fifty-three female patients (mean age $60 \pm 11.6$ years; range 33 to 85 years) fulfilling the clinical criteria for pSS were included in the study. To investigate the prevalence of EGM, a PubMed search from April 1976 to August 2012 identified 100 relevant publications by 88 authors, comprising a total of 14,861 pSS patients. An attempt was made to compare the obtained results regarding the prevalence of EGM with our results.

Results: In our study group, mean prevalence rate of EGM was $42.1 \%$ with a range from 0 to $92.5 \%$ compared to the range of 0.8 to $94 \%$ in the PubMed reports on EGM. Epidemiological studies involving large groups of patients tend to yield lower prevalence of EGM than studies based on a smaller sample size. We were unable to compare the reports of prevalence of EGM in patients with pSS due to different methodologies and classification criteria applied in the different studies.

Conclusion: The prevalence of pSS in this study was within the range of that reported in the literature. Due to methodological issues, we were unable to compare reports of prevalence of EGM in pSS. Our findings suggest that studies including larger sample sizes may be subjected to underreporting. Keywords: Extraglandular manifestations; prevalence; Sjögren's syndrome.
\end{abstract}

Sjögren's syndrome (SS), an autoimmune exocrinopathy with unknown etiology, is considered to be one the most common systemic inflammatory connective tissue diseases. A prevalence ranging from 0.04 to $0.66 \%$ has been reported for primary Sjögren's syndrome $(\mathrm{pSS})^{1,2}$ depending on the investigated populations and the classification criteria used. PSS affects particularly females in the fourth and fifth decades of life, with a female/male ratio of 9:1. The disease mainly affects the exocrine glands and usually presents itself as a persistent dryness of the mouth and eyes, resulting in functional impairment of the lacrimal and salivary glands due to lymphocytic infiltration and a subsequent loss of glandular tissue. Extraglandular organs may be complicated by the development of extraglandular involvement and organ-specific autoimmune disease. ${ }^{3}$ As patients with pSS may have involvement of many organs beyond the exocrine glands, the clinical manifestation of pSS is divided as exocrine gland features and extraglandular manifestations (EGM), ${ }^{4}$ the latter being experienced by a relatively high number 
of patients..$^{5-7}$ The development of other types of autoimmune diseases such as rheumatoid arthritis and systemic lupus erythematosus among patients with SS is also frequently observed. ${ }^{8,9}$ In this study, we aimed to investigate the prevalence of EGM in a group of Norwegian patients suffering from pSS and compare these findings with the literature.

\section{MATERIAL AND METHODS}

Fifty-three female patients (mean age $60 \pm 11.6$ years; range 33 to 85 years) were included in the study. All of the patients fulfilled the clinical criteria for $\mathrm{pSS}^{10}$ and data related to EGM was extracted from their journals, which was diagnosed on the basis of both subjective symptoms and objective signs, i.e. positive biopsies of minor labial salivary glands and pathological unstimulated salivary flow ( $\leq 0.1 \mathrm{~mL} / \mathrm{min})$.

To investigate the prevalence of EGM, a PubMed search from April 1976 to August 2012 identified 100 relevant publications by 88 authors, comprising a total of 14,861 pSS patients. An attempt was made to compare the obtained results regarding the prevalence of EGM with our results.

\section{RESULTS}

Mean prevalence rate of EGM was 42.1\%. In addition to EGM, the following symptoms were observed: osteoporosis (3.4\%), allergy (30.3\%), swollen glandules (34.8\%), swollen parotid gland (23.6\%), chilling (65.2\%), and diabetes mellitus (6.7\%).

Data from our study and the studies in PubMed on EGM and the frequencies of EGM in patients with pSS are shown in Table 1. While the prevalence range of EGM in PubMed reports was 0.8 to $94 \%$, the range in our study was 0 to $92.5 \%$. We were unable to compare the reports of prevalence of EGM in patients with pSS due to different methodologies and classification criteria applied in the different studies.

There was a significant negative correlation between the number of participants in the PubMed studies and the frequency of EGM (Spearman's correlation coefficient $=-0.42$; $\mathrm{p}<0.001$ ) (Figure 1).

Table 1. Summary statistics from studies included in PubMed search reporting on prevalence of extraglandular manifestations and our own results

\begin{tabular}{|c|c|c|c|c|c|c|}
\hline \multirow[t]{2}{*}{ Symptom/disease } & \multirow{2}{*}{$\frac{\text { Number of studies }}{\mathrm{n}}$} & \multicolumn{2}{|c|}{ Total number of patients } & \multicolumn{2}{|c|}{ EGM } & \multirow[t]{2}{*}{ References } \\
\hline & & $\mathrm{n}$ & Range & $\%$ & Range & \\
\hline $\begin{array}{l}\text { Fatigue } \\
\text { Our results }\end{array}$ & 13 & $\begin{array}{c}2435 \\
53\end{array}$ & $31-573$ & 92.5 & $13-86.5$ & $3,24,26-37$ \\
\hline $\begin{array}{l}\text { Lymphoma } \\
\text { Our results }\end{array}$ & 12 & $\begin{array}{c}1932 \\
53\end{array}$ & $31-536$ & 0 & $0-48.5$ & $3,14,22,29,31,36,38-44,75$ \\
\hline $\begin{array}{l}\text { Thyroiditis } \\
\text { Our results }\end{array}$ & 24 & $\begin{array}{c}3887 \\
53\end{array}$ & $9-573$ & 28.3 & $2.5-54$ & $4,22,24,29,30,31,33,39,45-59,75$ \\
\hline Lung disease & 33 & 6682 & $9-1010$ & & $2.6-80.7$ & $\begin{array}{l}4,20,24,29,31-33,36,39,42,53 \\
54,57,60-79\end{array}$ \\
\hline Our results & & 53 & & 6 & & \\
\hline Cutaneous symptoms & 24 & 6580 & $9-1010$ & & $2.7-80.8$ & $\begin{array}{l}4,20,22,24,26,29-33,36,42,44 \\
53,54,57,69,72,74,75,77,80-84\end{array}$ \\
\hline $\begin{array}{l}\text { Our results } \\
\text { Raynaud's phenomenon }\end{array}$ & 28 & $\begin{array}{c}53 \\
6286\end{array}$ & $9-1010$ & 90.6 & $10-81$ & $\begin{array}{l}3,4,6,13,20,22,24,26,29,32,33 \\
36,48,52,54,57,69,70,72,74-77 \\
81,83,85-87\end{array}$ \\
\hline Our results & & 53 & & 54.7 & & \\
\hline $\begin{array}{l}\text { Indigestion } \\
\text { Our results }\end{array}$ & 13 & $\begin{array}{c}1151 \\
53\end{array}$ & $13-573$ & 62.3 & $17.6-90$ & $24,74,88-97$ \\
\hline Liver disease & 22 & 3229 & $17-536$ & & $0.8-49.1$ & $\begin{array}{l}3,4,22,29,32,36,52,69,74,75 \\
81,90,98-109\end{array}$ \\
\hline Our results & & 53 & & 6.0 & & \\
\hline $\begin{array}{l}\text { Heart disease } \\
\text { Our results }\end{array}$ & 11 & $\begin{array}{c}1570 \\
53\end{array}$ & $10-573$ & 38.4 & $1.5-87.5$ & $24,32,42,52,69,81,110-114$ \\
\hline
\end{tabular}




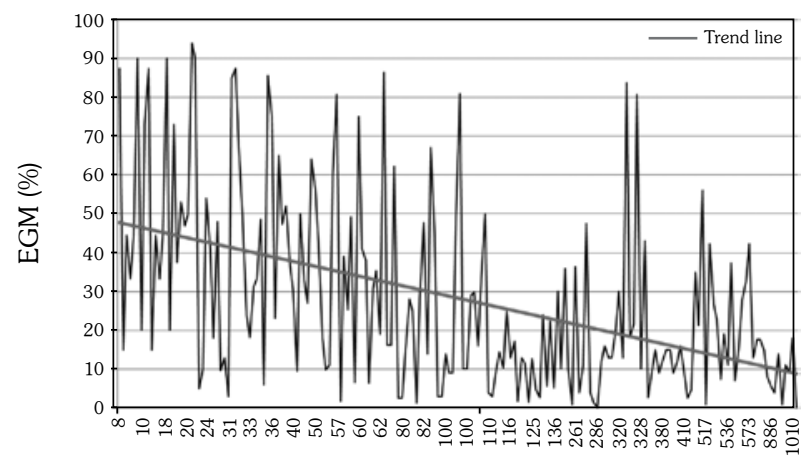

Total number of patients (100 publications)

Figure 1. Percentage of total number of extraglandular manifestations in relation to number of participants according to 100 PubMed studies. EGM: Extraglandular manifestations; Spearman's correlation coefficient $=-0.42 ; p<0.001$;

\section{DISCUSSION}

Clinimetrics, tools for assessing or describing symptoms, signs, and laboratory findings by means of scales, indices, and other quantitative instruments were not consistently used in the reviewed publications in PubMed on SS and EGM. The abundance of different measurement instruments in specific fields hampers the comparison of study results, and clinimetric properties are population and situation dependent. ${ }^{11}$ In diagnosing pSS, there are defined indices $^{12}$ and scales for EGM. ${ }^{13}$ Other types of EGM are usually diagnosed on the basis of both subjective symptoms and objective signs. Quantitative assessment of both clinical disease activity and organ damage in SS patients has been proposed. ${ }^{14,15}$ Also, a damage index and disease activity index, i.e. scoring systems for the assessment of disease damage and disease activity in SS patients were proposed..$^{15,16}$ There is a need for validated indexes that evaluate disease reversible activity and permanent damage. ${ }^{13}$

There is no agreement concerning the sets of classification criteria for SS. ${ }^{17}$ When the San Diego criteria are used, only $15 \%$ of patients fulfilling the European criteria for $\mathrm{SS}^{10}$ will be diagnosed as SS - a fact that must be considered when evaluating reports on SS. ${ }^{18}$ According to the classification criteria of the American-European Consensus Group, ${ }^{19}$ the prevalence of pSS is far lower than previously assumed, and the reported male/female ratio of 1:9 seems to lie more in the range of $1: 20 .{ }^{20}$ Use of the American-European Consensus Group criteria will probably result in the participation of fewer males, as well as younger patients in general, and more severely ill patients in future cohort investigations. ${ }^{21}$ Information regarding age at disease onset has changed over the last decade, as recent studies are indicating an onset age of approximately 45 years, compared to 56 in earlier studies. ${ }^{21}$

There is a limitation of studies on EGM in pSS in the completely healthy (asymptomatic) control groups of individuals: "It is not feasible to assemble sufficiently large, populationbased control groups of completely healthy individuals". ${ }^{22}$ Variations detected by Sjögren's International Collaborative Clinical Alliance Registry ${ }^{22}$ in the actual populations, recruitment sources, investigation methods as well as the inclusion criteria and definitions regarding organ involvement utilized by the various investigators may, together with environmental factors, genetic, and race differences, be the causes for such differences. Furthermore, there is a relationship between the number of systemic autoantibodies and the number of EGM in pSS with a high prevalence of anti-Sjögren syndrome A antigen, anti-Sjögren syndrome $\mathrm{B}$ antigen, anti-nuclear antibodies, and immunoglobulin M-rheumatoid factor antibodies, indicating that a more disturbed immune system (as characterized by the presence of hypergammaglobulinemia and multiple autoantibodies formed by hyper-reactive B-cells) may result in more EGM. ${ }^{23}$

The number of patients in our clinical investigation may be limited to draw firm conclusions; however, our results support those reported in the literature. Similarly, 42 of the 100 publications in PubMed had 53 or fewer patients. The percentages of EGM in our study were generally higher compared to the percentages drawn from PubMed but still within the range of PubMed percentages (0.8 to $94 \%$, Table 1 ). This difference may be due to the diagnostic criteria utilized, i.e. whether the diagnosis was based on the patients' subjective report or on objective medical information. Also, the selection of patients may have been of importance.

In their study, Lin et al. ${ }^{24}$ showed systemic detriment in as much as $91.4 \%$ of inpatients with pSS. This high percentage was explained by the application of more advanced methods for diagnosing early organ damage. Another 
explanation may be that this particular group of pSS patients were more severely ill, since hospitalized. Our patients came from a private dental clinic and symptoms/diagnoses were extracted from the patients' journals in which diagnosis was made on the basis of both subjective symptoms and objective signs, which again may explain the diverging prevalence of EGM.

One unexpected finding has been that according to the PubMed search, studies with higher numbers of investigated patients resulted in decreased prevalence of EGM, as compared to studies with fewer number of patients (Figure 1). It is tempting to speculate that the reason for this lower prevalence in studies with more participants may be that the time allocated for individual examinations may have been shorter due to the high number of participants. The presumed time limitation might thus have resulted in less scrutiny. Another explanation may be that only findings based on objective medical investigations were used in those studies and not self-reports, which may underestimate the prevalence of some systemic disorders. ${ }^{25}$ If so, this raises a question towards epidemiological studies based on a vast number of patients. That is, can a smaller group of examined patients raise the quality of the investigation? In our study where we had a relatively low number of participants with a relatively high number of reported EGM, it was possible to allocate ample time for completion of the questionnaire. Nevertheless, decreasing prevalence of EGM with increasing number of participants in epidemiological studies needs to be considered when evaluating the prevalence of EGM in pSS patients, which again calls for further investigation. In this study, our objective was to compare our results with the mean prevalence found in the PubMed investigation; however, based on the above discussion, it is difficult to make a reliable comparison of EGM prevalence rates.

In conclusion, our extensive review of 100 publications from Asia, Europe, Africa, and America shows that EGM in patients suffering from pSS is common. There was a significant range of prevalence in the PubMed reports on EGM. The use of different classification criteria and lack of control groups in some studies should be taken into consideration regarding the data from the studies included in this article. Also, it should be kept in mind that epidemiological studies involving large groups of patients tend to yield lower prevalence of EGM than studies based on a smaller sample size.

\section{Declaration of conflicting interests}

The authors declared no conflicts of interest with respect to the authorship and/or publication of this article.

\section{Funding}

The authors received no financial support for the research and/or authorship of this article.

\section{REFERENCES}

1. Bowman SJ, Ibrahim GH, Holmes G, Hamburger $\mathrm{J}$, Ainsworth JR. Estimating the prevalence among Caucasian women of primary Sjögren's syndrome in two general practices in Birmingham, UK. Scand J Rheumatol 2004;33:39-43.

2. Birlik M, Akar S, Gurler O, Sari I, Birlik B, Sarioglu $\mathrm{S}$, et al. Prevalence of primary Sjogren's syndrome in Turkey: a population-based epidemiological study. Int J Clin Pract 2009;63:954-61.

3. Kruize AA, Hené RJ, van der Heide A, Bodeutsch $\mathrm{C}$, de Wilde $\mathrm{PC}$, van Bijsterveld $\mathrm{OP}$, et al. Longterm followup of patients with Sjögren's syndrome. Arthritis Rheum 1996;39:297-303.

4. Asmussen K, Andersen V, Bendixen G, Schiødt M, Oxholm P. A new model for classification of disease manifestations in primary Sjögren's syndrome: evaluation in a retrospective long-term study. J Intern Med 1996;239:475-82.

5. Mahoney EJ, Spiegel JH. Sjögren's disease. Otolaryngol Clin North Am 2003;36:733-45.

6. Ramos-Casals M, Loustaud-Ratti V, De Vita S, Zeher $\mathrm{M}$, Bosch JA, Toussirot E, et al. Sjögren syndrome associated with hepatitis $C$ virus: a multicenter analysis of 137 cases. Medicine (Baltimore) 2005;84:81-9.

7. Hansen $A$, Dörner $T$. Sjögren syndrome. Internist (Berl) 2010;51:1267-79.

8. Lazarus MN, Isenberg DA. Development of additional autoimmune diseases in a population of patients with primary Sjögren's syndrome. Ann Rheum Dis 2005;64:1062-4.

9. Jonsson R, Bowman SJ, Gordon TP. Sjøgren's syndrome. In: Koopman WJ, Moreland LW, editors. Arthritis and Allied Conditions. 15th ed. Philadelphia: Lippincott Williams \& Wilkins; 2004. p. 1681-705.

10. Vitali C, Bombardieri S, Moutsopoulos HM, Balestrieri G, Bencivelli W, Bernstein RM, et al. Preliminary criteria for the classification of Sjögren's syndrome. Results of a prospective concerted action supported by the European Community. Arthritis Rheum 1993;36:340-7. 
11. de Vet HC, Terwee CB, Bouter LM. Current challenges in clinimetrics. J Clin Epidemiol 2003;56:1137-41.

12. Manthorpe R, Jacobsson LT, Kirtava Z, Theander E. Epidemiology of Sjögren's syndrome, especially its primary form. Ann Med Interne (Paris) 1998;149:7-11.

13. Hernández-Molina G, Sánchez-Hernández T. Clinimetric methods in Sjögren's syndrome. Semin Arthritis Rheum 2013;42:627-39.

14. Asmussen K, Andersen V, Bendixen G, Bendtzen K, Prause JU, Thorn J, et al. Quantitative assessment of clinical disease status in primary Sjögren's syndrome. A cross-sectional study using a new classification model. Scand J Rheumatol 1997;26:197-205.

15. Vitali C, Palombi G, Baldini C, Benucci M, Bombardieri $\mathrm{S}$, Covelli M, et al. Sjögren's Syndrome Disease Damage Index and disease activity index: scoring systems for the assessment of disease damage and disease activity in Sjögren's syndrome, derived from an analysis of a cohort of Italian patients. Arthritis Rheum 2007;56:2223-31.

16. Campar A, Isenberg DA. Primary Sjögren's syndrome activity and damage indices comparison. Eur J Clin Invest 2010;40:636-44.

17. Daniels TE. Sjogren's syndrome: clinical spectrum and current diagnostic controversies. Adv Dent Res 1996;10:3-8.

18. Fox RI. Sjøgren's syndrome. In: Kelly ED, Harris ED, Shaun R, Sledge CB, editors. Textbook of Rheumatology. 5th ed. Philadephia: W.B. Saunders; 1997 p. 955.

19. Vitali C, Bombardieri S, Jonsson R, Moutsopoulos HM, Alexander EL, Carsons SE, et al. Classification criteria for Sjögren's syndrome: a revised version of the European criteria proposed by the AmericanEuropean Consensus Group. Ann Rheum Dis 2002;61:554-8.

20. Alamanos Y, Tsifetaki N, VoulgariPV, Venetsanopoulou AI, Siozos C, Drosos AA. Epidemiology of primary Sjögren's syndrome in north-west Greece, 19822003. Rheumatology (Oxford) 2006;45:187-91.

21. Westhoff G, Zink A. Epidemiology of primary Sjörgren's syndrome. Z Rheumatol 2010;69:41-9.

22. Malladi AS, Sack KE, Shiboski SC, Shiboski CH, Baer AN, Banushree R, et al. Primary Sjögren's syndrome as a systemic disease: a study of participants enrolled in an international Sjögren's syndrome registry. Arthritis Care Res (Hoboken) 2012;64:911-8.

23. ter Borg EJ, Risselada AP, Kelder JC. Relation of systemic autoantibodies to the number of extraglandular manifestations in primary Sjögren's Syndrome: a retrospective analysis of 65 patients in the Netherlands. Semin Arthritis Rheum 2011;40:547-51.

24. Lin DF, Yan SM, Zhao Y, Zhang W, Li MT, Zeng XF, et al. Clinical and prognostic characteristics of 573 cases of primary Sjögren's syndrome. Chin Med J (Engl) 2010;123:3252-7.

25. Aoki Y, Belin RM, Clickner R, Jeffries R, Phillips L,
Mahaffey KR. Serum TSH and total T4 in the United States population and their association with participant characteristics: National Health and Nutrition Examination Survey (NHANES 1999-2002). Thyroid 2007; 17:1211-23.

26. Markusse HM, Oudkerk M, Vroom TM, Breedveld FC. Primary Sjögren's syndrome: clinical spectrum and mode of presentation based on an analysis of 50 patients selected from a department of rheumatology. Neth J Med 1992;40:125-34.

27. Gudbjörnsson B, Broman JE, Hetta J, Hällgren R. Sleep disturbances in patients with primary Sjögren's syndrome. Br J Rheumatol 1993;32:1072-6.

28. Barendregt PJ, Visser MR, Smets EM, Tulen JH, van den Meiracker AH, Boomsma F, et al. Fatigue in primary Sjögren's syndrome. Ann Rheum Dis 1998;57:291-5.

29. Voulgarelis M, Dafni UG, Isenberg DA, Moutsopoulos HM. Malignant lymphoma in primary Sjögren's syndrome: a multicenter, retrospective, clinical study by the European Concerted Action on Sjögren's Syndrome. Arthritis Rheum 1999;42:1765-72.

30. Davidson BK, Kelly CA, Griffiths ID. Primary Sjögren's syndrome in the North East of England: a long-term follow-up study. Rheumatology (Oxford) 1999;38:245-53.

31. Manthorpe R, Kirtava Z, Tabery H, Henriksson H, Theander E, Jacobsson L. Clinical and laboratory data analysis from 328 patients with primary Sjøgren's syndrome. In: Eriksson P, Jonsson R, editors. State of the art lectures on Sjøgren's syndrome and historical perspectives. Stockholm: Swedish Society of Medicine; 1999. Available from: http://i5.archivec. com/files/2010/05/25/11378/15ce06a21b6dd46d7 6b6f66b5e72c6b2.pdf

32. Skopouli FN, Dafni U, Ioannidis JP, Moutsopoulos HM. Clinical evolution, and morbidity and mortality of primary Sjögren's syndrome. Semin Arthritis Rheum 2000;29:296-304.

33. García-Carrasco M, Sisó A, Ramos-Casals M, Rosas $\mathrm{J}$, de la Red G, Gil V, et al. Raynaud's phenomenon in primary Sjögren's syndrome. Prevalence and clinical characteristics in a series of 320 patients. J Rheumatol 2002;29:726-30.

34. Hartkamp A, Geenen R, Bijl M, Kruize AA, Godaert GL, Derksen RH. Serum cytokine levels related to multiple dimensions of fatigue in patients with primary Sjogren's syndrome. Ann Rheum Dis 2004;63:1335-7.

35. Segal B, Thomas W, Rogers T, Leon JM, Hughes P, Patel D, et al. Prevalence, severity, and predictors of fatigue in subjects with primary Sjögren's syndrome. Arthritis Rheum 2008;59:1780-7.

36. Baimpa E, Dahabreh IJ, Voulgarelis M, Moutsopoulos HM. Hematologic manifestations and predictors of lymphoma development in primary Sjögren syndrome: clinical and pathophysiologic aspects. Medicine (Baltimore) 2009;88:284-93. 
37. Priori R, Iannuccelli $C$, Alessandri C, Modesti M, Antonazzo B, Di Lollo AC, et al. Fatigue in Sjogren's syndrome: relationship with fibromyalgia, clinical and biologic features. Clin Exp Rheumatol 2010;28:82-6.

38. Kassan SS, Thomas TL, Moutsopoulos HM, Hoover R, Kimberly RP, Budman DR, et al. Increased risk of lymphoma in sicca syndrome. Ann Intern Med 1978;89:888-92.

39. Kelly CA, Foster H, Pal B, Gardiner P, Malcolm AJ, Charles $\mathrm{P}$, et al. Primary Sjögren's syndrome in north east England--a longitudinal study. $\mathrm{Br} \mathrm{J}$ Rheumatol 1991;30:437-42.

40. Pariente D, Anaya JM, Combe B, Jorgensen C, Emberger JM, Rossi JF, et al. Non-Hodgkin's lymphoma associated with primary Sjögren's syndrome. Eur J Med 1992;1:337-42.

41. Valesini G, Priori R, Bavoillot D, Osborn J, Danieli MG, Del Papa N,et al. Differential risk of non-Hodgkin's lymphoma in Italian patients with primary Sjögren's syndrome. J Rheumatol 1997;24:2376-80.

42. Kruize AA. Prognosis and long-term outcome in primary Sjøgren's syndrome. In: Eriksson P, Jonsson $\mathrm{R}$, editors. State of the art lectures on Sjøgren's syndrome and historical perspectives. Stockholm: Swedish Society of Medicine; 1999. Available from: http://i5.archivec.com/files/2010/05/25/11378/bf4 6e46bd98448662642b67ceab21df6.pdf.

43. Lazarus MN, Robinson D, Mak V, Møller $\mathrm{H}$, Isenberg DA. Incidence of cancer in a cohort of patients with primary Sjogren's syndrome. Rheumatology (Oxford) 2006;45:1012-5.

44. Theander E, Henriksson G, Ljungberg O, Mandl T, Manthorpe R, Jacobsson LT. Lymphoma and other malignancies in primary Sjögren's syndrome: a cohort study on cancer incidence and lymphoma predictors. Ann Rheum Dis 2006;65:796-803.

45. Karsh J, Pavlidis N, Weintraub BD, Moutsopoulos HM. Thyroid disease in Sjögren's syndrome. Arthritis Rheum 1980;23:1326-9.

46. Hansen BU, Ericsson UB, Henricsson V, Larsson A, Manthorpe R, Warfvinge G. Autoimmune thyroiditis and primary Sjögren's syndrome: clinical and laboratory evidence of the coexistence of the two diseases. Clin Exp Rheumatol 1991;9:137-41.

47. Pérez B, Kraus A, López G, Cifuentes M, AlarcónSegovia D. Autoimmune thyroid disease in primary Sjögren's syndrome. Am J Med 1995;99:480-4.

48. Foster H, Fay A, Kelly C, Charles P, Walker D, Griffiths I. Thyroid disease and other autoimmune phenomena in a family study of primary Sjögren's syndrome. Br J Rheumatol 1993;32:36-40.

49. Punzi L, Ostuni PA, Betterle C, De Sandre P, Botsios C, Gambari PF. Thyroid gland disorders in primary Sjögren's syndrome. Rev Rhum Engl Ed 1996;63:809-14.

50. Figueirinhas J, Vaz Patto J, Cruz Martins J, Benevenuta Esquivel M, Silva Margarida M, Gil Forte J.
Portuguese Study Group of Sjøgren's syndrome. In: Eriksson P, Jonsson R, editors. Salivary glands and thyroid ultrasonography in Sjøgren's syndrome. State of the art lectures on Sjøgren's syndrome and historical perspectives. Stockholm: Swedish Society of Medicine; 1999. Available from: http://i5.archivec. com/files/2010/05/25/11378/1c5c1876d84e75a6b 4a8ba9510ae54d9.pdf.

51. Ramos-Casals M, García-Carrasco M, Cervera R, Gaya J, Halperin I, Ubieto I, et al. Thyroid disease in primary Sjögren syndrome. Study in a series of 160 patients. Medicine (Baltimore) 2000;79:103-8.

52. Pertovaara M, Pukkala E, Laippala P, Miettinen A, Pasternack A. A longitudinal cohort study of Finnish patients with primary Sjögren's syndrome: clinical, immunological, and epidemiological aspects. Ann Rheum Dis 2001;60:467-72.

53. Ramos-Casals M, Font J, Garcia-Carrasco M, Brito MP, Rosas J, Calvo-Alen J, et al. Primary Sjögren syndrome: hematologic patterns of disease expression. Medicine (Baltimore) 2002;81:281-92.

54. García-Carrasco M, Ramos-Casals M, Rosas J, Pallarés L, Calvo-Alen J, Cervera R, et al. Primary Sjögren syndrome: clinical and immunologic disease patterns in a cohort of 400 patients. Medicine (Baltimore) 2002;81:270-80.

55. D'Arbonneau F, Ansart S, Le Berre R, Dueymes M, Youinou P, Pennec YL. Thyroid dysfunction in primary Sjögren's syndrome: a long-term followup study. Arthritis Rheum 2003;49:804-9.

56. Tunc R, Gonen MS, Acbay O, Hamuryudan V, Yazici $\mathrm{H}$. Autoimmune thyroiditis and anti-thyroid antibodies in primary Sjogren's syndrome: a case-control study. Ann Rheum Dis 2004;63:575-7.

57. Launay D, Hachulla E, Hatron PY, Jais X, Simonneau G, Humbert M. Pulmonary arterial hypertension: a rare complication of primary Sjögren syndrome: report of 9 new cases and review of the literature. Medicine (Baltimore) 2007;86:299-315.

58. Zeher M, Horvath IF, Szanto A, Szodoray P. Autoimmune thyroid diseases in a large group of Hungarian patients with primary Sjögren's syndrome. Thyroid 2009;19:39-45.

59. Kohriyama K, Katayama Y, Tsurusako Y. Relationship between primary Sjögren's syndrome and autoimmune thyroid disease. Nihon Rinsho 1999;57:1878-81.

60. Oxholm P, Bundgaard A, Birk Madsen E, Manthorpe $\mathrm{R}$, Vejlø Rasmussen F. Pulmonary function in patients with primary Sjögren's syndrome. Rheumatol Int 1982;2:179-81.

61. Constantopoulos SH, Papadimitriou CS, Moutsopoulos HM. Respiratory manifestations in primary Sjögren's syndrome. A clinical, functional, and histologic study. Chest 1985;88:226-9.

62. Papathanasiou MP, Constantopoulos SH, Tsampoulas C, Drosos AA, Moutsopoulos HM. Reappraisal of respiratory abnormalities in primary and secondary 
Sjögren's syndrome. A controlled study. Chest 1986;90:370-4.

63. Constantopoulos SH, Moutsopoulos HM. Respiratory involvement in patients with Sjögren's syndrome: is it a problem? Scand J Rheumatol Suppl 1986;61:146-50.

64. Gudbjörnsson B, Hedenström H, Stålenheim G, Hällgren R. Bronchial hyperresponsiveness to methacholine in patients with primary Sjögren's syndrome. Ann Rheum Dis 1991;50:36-40.

65. Gardiner P. Primary Sjögren's syndrome. Baillieres Clin Rheumatol 1993;7:59-77.

66. Lahdensuo A, Korpela M. Pulmonary findings in patients with primary Sjögren's syndrome. Chest 1995;108:316-9.

67. Deheinzelin D, Capelozzi VL, Kairalla RA, Barbas Filho JV, Saldiva PH, de Carvalho CR. Interstitial lung disease in primary Sjögren's syndrome. Clinicalpathological evaluation and response to treatment. Am J Respir Crit Care Med 1996;154:794-9.

68. Mialon P, Barthélémy L, Sébert P, Le Hénaff C, Sarni D, Pennec YL, et al. A longitudinal study of lung impairment in patients with primary Sjögren's syndrome. Clin Exp Rheumatol 1997;15:349-54.

69. Zhao Y, Dong Y, Guo XP, Tang FL. Clinical analysis of primary Sjøgren's syndrome. Beijing Med 1997;19:100-4.

70. Papiris SA, Maniati M, Constantopoulos SH, Roussos C, Moutsopoulos HM, Skopouli FN. Lung involvement in primary Sjögren's syndrome is mainly related to the small airway disease. Ann Rheum Dis 1999;58:61-4.

71. Uffmann M, Kiener HP, Bankier AA, Baldt MM, Zontsich T, Herold CJ. Lung manifestation in asymptomatic patients with primary Sjögren syndrome: assessment with high resolution $\mathrm{CT}$ and pulmonary function tests. J Thorac Imaging 2001;16:282-9.

72. Ramos-Casals M, Brito-Zerón P, Yagüe J, Akasbi M, Bautista R, Ruano M, et al. Hypocomplementaemia as an immunological marker of morbidity and mortality in patients with primary Sjogren's syndrome. Rheumatology (Oxford) 2005;44:89-94.

73. Parambil JG, Myers JL, Lindell RM, Matteson EL, Ryu JH. Interstitial lung disease in primary Sjögren syndrome. Chest 2006;130:1489-95.

74. Mandl T, Ekberg O, Wollmer P, Manthorpe R, Jacobsson LT. Dysphagia and dysmotility of the pharynx and oesophagus in patients with primary Sjögren's syndrome. Scand J Rheumatol 2007;36:394-401.

75. Seo SH, Kim HS, Kwok SK, Ju JH, Kim SH, Yoon CH, et al. Extraglandular manifestations and autoantibodies of Korean patients with primary Sjogren's syndrome. J Korean Rheum Assoc 2007;14:43-50.

76. Yan SM, Zhao Y, Zeng XF, Zhang FC, Dong Y. Lung involvement of primary Sjögren's syndrome. Zhonghua Jie He He Hu Xi Za Zhi 2008;31:513-6.

77. Ramos-Casals M, Solans R, Rosas J, Camps MT, Gil A, Del Pino-Montes J, et al. Primary Sjögren syndrome in Spain: clinical and immunologic expression in 1010 patients. Medicine (Baltimore) 2008;87:210-9.

78. Yazisiz V, Arslan G, Ozbudak IH, Turker S, Erbasan $\mathrm{F}$, Avci $\mathrm{AB}$, et al. Lung involvement in patients with primary Sjögren's syndrome: what are the predictors? Rheumatol Int 2010;30:1317-24.

79. Soto-Cardenas MJ, Perez-De-Lis M, Bove A, Navarro C, Brito-Zeron P, Diaz-Lagares C, et al. Bronchiectasis in primary Sjögren's syndrome: prevalence and clinical significance. Clin Exp Rheumatol 2010;28:647-53.

80. Zufferey P, Meyer OC, Grossin M, Kahn MF. Primary Sjögren's syndrome (SS) and malignant lymphoma. A retrospective cohort study of 55 patients with SS. Scand J Rheumatol 1995;24:342-5.

81. Kaplan MJ, Ike RW. The liver is a common nonexocrine target in primary Sjögren's syndrome: a retrospective review. BMC Gastroenterol 2002;2:21.

82. Ioannidis JP, Vassiliou VA, Moutsopoulos HM. Longterm risk of mortality and lymphoproliferative disease and predictive classification of primary Sjögren's syndrome. Arthritis Rheum 2002;46:741-7.

83. Bernacchi E, Amato L, Parodi A, Cottoni F, Rubegni $\mathrm{P}, \mathrm{De}$ Pità $\mathrm{O}$, et al. Sjögren's syndrome: a retrospective review of the cutaneous features of 93 patients by the Italian Group of Immunodermatology. Clin Exp Rheumatol 2004;22:55-62.

84. Ramos-Casals M, Anaya JM, García-Carrasco M, Rosas J, Bové A, Claver G, et al. Cutaneous vasculitis in primary Sjögren syndrome: classification and clinical significance of 52 patients. Medicine (Baltimore) 2004;83:96-106.

85. Youinou P, Pennec YL, Katsikis P, Jouquan J, Fauquert $\mathrm{P}$, Le Goff P. Raynaud's phenomenon in primary Sjögren's syndrome. Br J Rheumatol 1990;29:205-7.

86. Skopouli FN, Talal A, Galanopoulou V, Tsampoulas CG, Drosos AA, Moutsopoulos HM. Raynaud's phenomenon in primary Sjögren's syndrome. J Rheumatol 1990;17:618-20.

87. Kraus A, Caballero-Uribe C, Jakez J, Villa AR, Alarcón-Segovia D. Raynaud's phenomenon in primary Sjögren's syndrome. Association with other extraglandular manifestations. J Rheumatol 1992;19:1572-4.

88. Ramirez-Mata M, Pena Ancira FF, Alarcon-Segovia D. Abnormal esophageal motility in primary Sjögren's syndrome. J Rheumatol 1976;3:63-9.

89. Maury CP, Törnroth T, Teppo AM. Atrophic gastritis in Sjögren's syndrome. Morphologic, biochemical, and immunologic findings. Arthritis Rheum. 1985;28:388-94.

90. Tsianos EB, Vasakos S, Drosos AA, MalamouMitsi VD, Moutsopoulos HM. The gastrointestinal involvement in primary Sjögren's syndrome. Scand J Rheumatol Suppl 1986;61:151-5.

91. Kjellén G, Fransson SG, Lindström F, Sökjer $H$, Tibbling L. Esophageal function, radiography, and dysphagia in Sjögren's syndrome. Dig Dis Sci 1986;31:225-9. 
92. Pokorny G, Karácsony G, Lonovics J, Hudák J, Németh J, Varró V. Types of atrophic gastritis in patients with primary Sjögren's syndrome. Ann Rheum Dis 1991;50:97-100.

93. Grande L, Lacima G, Ros E, Font J, Pera C. Esophageal motor function in primary Sjögren's syndrome. Am J Gastroenterol 1993;88:378-81.

94. Ostuni PA, Germana B, Di Mario F, Rugge M, Plebani M, De Zambiasi P, et al. Gastric involvement in primary Sjögren's syndrome. Clin Exp Rheumatol 1993;11:21-5.

95. Collin P, Karvonen AL, Korpela M, Laippala P, Helin H. Gastritis classified in accordance with the Sydney system in patients with primary Sjögren's syndrome. Scand J Gastroenterol 1997;32:108-11.

96. Anselmino M, Zaninotto G, Costantini M, Ostuni $\mathrm{P}$, Ianniello A, Boccú C, et al. Esophageal motor function in primary Sjögren's syndrome: correlation with dysphagia and xerostomia. Dig Dis Sci 1997;42:113-8.

97. El Miedany YM, Baddour M, Ahmed I, Fahmy H. Sjogren's syndrome: concomitant $\mathrm{H}$. pylori infection and possible correlation with clinical parameters. Joint Bone Spine 2005;72:135-41.

98. Tsianos EV, Hoofnagle JH, Fox PC, Alspaugh M, Jones EA, Schafer DF, et al. Sjögren's syndrome in patients with primary biliary cirrhosis. Hepatology 1990;11:730-4.

99. Lindgren S, Manthorpe R, Eriksson S. Autoimmune liver disease in patients with primary Sjögren's syndrome. J Hepatol 1994;20:354-8.

100. Furuya T, Tateishi M, Nishinarita M, Kashiwazaki S. Primary biliary cirrhosis in patients with Sjögren's syndrome. Nihon Rinsho 1995;53:2536-9.

101. Jorgensen $\mathrm{C}$, Legouffe MC, Perney $\mathrm{P}$, Coste J, Tissot B, Segarra C, et al. Sicca syndrome associated with hepatitis $\mathrm{C}$ virus infection. Arthritis Rheum 1996;39:1166-71.

102. García-Carrasco M, Ramos M, Cervera R, Font J, Vidal J, Muñoz FJ, et al. Hepatitis $C$ virus infection in 'primary' Sjögren's syndrome: prevalence and clinical significance in a series of 90 patients. Ann Rheum Dis 1997;56:173-5.

103. Zhang Z, Dong Y. Clinical manifestations and immunological features of primary Sjögren's syndrome with liver involvement: analysis of thirty cases. Chin Med J (Engl) 1998;111:220-3.

104. Matsumoto T, Morizane T, Aoki Y, Yamasaki S,
Nakajima M, Enomoto N, et al. Autoimmune hepatitis in primary Sjogren's syndrome: pathological study of the livers and labial salivary glands in 17 patients with primary Sjogren's syndrome. Pathol Int 2005;55:70-6.

105. Montaño-Loza AJ, Crispín-Acuña JC, RemesTroche JM, Uribe M. Abnormal hepatic biochemistries and clinical liver disease in patients with primary Sjögren's syndrome. Ann Hepatol 2007;6:150-5.

106. Hatzis GS, Fragoulis GE, Karatzaferis A, Delladetsima I, Barbatis C, Moutsopoulos HM. Prevalence and longterm course of primary biliary cirrhosis in primary Sjögren's syndrome. J Rheumatol 2008;35:2012-6.

107. Karp JK, Akpek EK, Anders RA. Autoimmune hepatitis in patients with primary Sjögren's syndrome: a series of two-hundred and two patients. Int J Clin Exp Pathol 2010;3:582-6.

108. Marcos M, Alvarez F, Brito-Zerón P, Bove A, PerezDe-Lis M, Diaz-Lagares C, et al. Chronic hepatitis $B$ virus infection in Sjögren's syndrome. Prevalence and clinical significance in 603 patients. Autoimmun Rev 2009;8:616-20.

109. Chen MH, Hsiao LT, Chen MH, Tsai CY, Huang YH, Chou CT. Clinical significance of chronic hepatitis $B$ virus infection in patients with primary Sjögren's syndrome. Clin Rheumatol 2012;31:309-15.

110. Gyöngyösi M, Pokorny G, Jambrik Z, Kovács L, Kovács A, Makula E, et al. Cardiac manifestations in primary Sjögren's syndrome. Ann Rheum Dis 1996;55:450-4

111. Andonopoulos AP, Christodoulou J, Ballas C, Bounas A, Alexopoulos D. Autonomic cardiovascular neuropathy in Sjögren's syndrome. A controlled study. J Rheumatol 1998;25:2385-8.

112. Kovács L, Paprika D, Tákacs R, Kardos A, Várkonyi TT, Lengyel C, et al. Cardiovascular autonomic dysfunction in primary Sjögren's syndrome. Rheumatology (Oxford) 2004;43:95-9.

113. Lodde BM, Sankar V, Kok MR, Leakan RA, Tak PP, Pillemer SR. Adult heart block is associated with disease activity in primary Sjögren's syndrome. Scand J Rheumatol 2005;34:383-6.

114. Vassiliou VA, Moyssakis I, Boki KA, Moutsopoulos HM. Is the heart affected in primary Sjögren's syndrome? An echocardiographic study. Clin Exp Rheumatol 2008;26:109-12. 